\title{
A model NOT to be imitated?: Recent criticisms of Paul ${ }^{1}$
}

\author{
Johan Strijdom \\ Department of Classics \\ University of South Africa
}

\begin{abstract}
In this article recent criticisms of Paul are summarised under the headings of ethnicity (Mack), social class (Theissen), gender (Wire) and homoeroticism (Nissinen). Horsley's positive appraisal of Paul's anti-imperial stance is also surveyed. These views are introduced by means of the concept of imitation as a category of social ethics in Paul, the article, concludes with a statement on the morality of reading.
\end{abstract}

The principal deficiency in biblical scholarship currently is its lack of a myth criticism. We have developed historical criticism to a high art, but we have been unable to conceive a critical relation to the stories that undergird our tradition and limit our vision. In the next phase of our work, we must remedy this fundamental deficiency.

(Funk 1996:309)

Tell us the content of your vision. And then we will have to judge ... whether we should follow it or not.

(Crossan 1998:xviii)

1 The financial assistance of the Division for Social Sciences and Humanities of the National Research Foundation (South Africa) towards this research is hereby acknowledged. Opinions expressed and conclusions arrived at are those of the author and are not necessarily to be attributed to the National Research Foundation. 


\section{INTRODUCTION}

Paul as model. Christ as model. The pattern is clear. Paul can and does exhort his recipients to follow his example. He, in turn, claims to follow Christ's. Thus, in 1

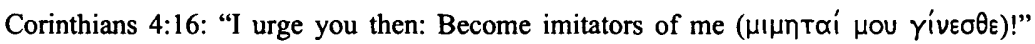

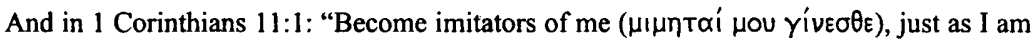

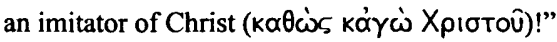

Or in Philippians, again, he can and does quote a hymn to present Christ to his audience as the ultimate model to be copied: "You should have the same attitude among

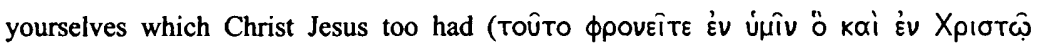

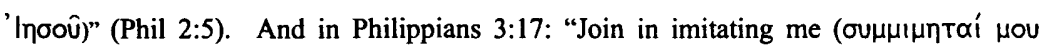
Yíve $\theta \varepsilon)$, brothers and sisters, and pay attention to those whose behaviour is in

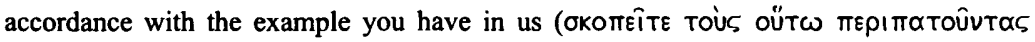

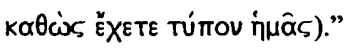

Indeed, already in his earliest letter he can and does praise the Thessalonians for having emulated the appropriate models: "You have already become imitators of us and of the Lord (ن் in the same letter, "For you have become, brothers and sisters, imitators of God's

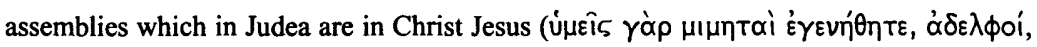

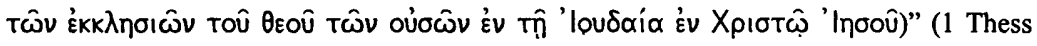
2:14).

The crucial question, however, if we may appropriate Crossan's quotation above for our purposes here, should plainly be: What was the content to be imitated? Restated in different terms: How did Paul's Christ myth serve to legitimize the social ethics that he proclaimed? And, even more importantly, should that program be repeated in our own times, or should it rather be seriously criticized? In this article I will briefly outline a few answers that have recently been given by some critical scholars. First, however, I need make a preliminary remark on my definition and understanding of myth.

Myths are, on my understanding, imaginative products of specific societies, and these societies are, in turn, influenced, for better or for worse, by the very fantasies they create. In a narrow sense the term refers to stories about divine intervention in human affairs, in which case it serves as a synonym for theology. Thus we may speak of the 
theology/mythology of Homer or Euripides, of the Jahwist or Mark or Paul. In a broader sense the concept may be used to refer to any ideological construct by which a society lives, for example Marxism, or Nationalism, or Apartheid. The important point to see in both cases is that myths are woven by human beings, and that they either confirm or challenge the power relations of a particular society. With that social understanding of myth in place, we may now turn to Paul in order to assess his ideas on ethnic, class, gender, and sexual relations.

\section{ETHNICITY}

According to Burton Mack (1995:75-96), pre-Pauline fragments (specifically Rom 3:2426, 1 Cor 15:3-5, and Phil 2:6-11) provide evidence of ethnically mixed Christ cults in the cities of Syria, Asia-Minor, and Greece. Those associations not only thought that it was the death of Christ, their cult god, that brought their mixed constitution about, but also added the myth of Christ's resurrection in order to imagine that God actually approved of their social experiment. The final step was taken when Christ was imagined as the cosmic Lord above all other Greco-Roman competitors - above Isis, for example, or Caesar. That new mythical construct served as a response to their own multicultural context, and claimed that their ethnically mixed subculture provided an answer to the confusion of their cosmopolitan world. Mack maintains that such a minority claim would have been "audacious" and would surely "have sounded absurd, pretentious, and downright dangerous for good relations with friendly neighbors" (:95).

Paul's conversion should, in Mack's view, then be understood as a change of social vision. The conservative Pharisee, who had expected non-Jews to be circumcised in order to join Syrian diaspora synagogues and who had opposed Christians who held the opposite view, now became convinced that those Christians were right. An entirely new horizon opened up to him: the whole of humanity could be converted to his viewpoint before the apocalyptic finale, which required an intense missionary program from his side. Mack remarks: "Gentiles were now to be summoned as well as welcomed into the house of Israel. From Paul's Jewish point of view that was a very big deal. It does not seem to have crossed his mind that all gentiles may not have been impressed" (:105). 
That Paul understood the rationale of the Christ myth well is also clear from the way in which he appropriated the Jewish epic in order to show that God had the Gentile nations in mind in his plan all along. In Galatians, for example, Paul tries to show that the Gentile Christians are in fact "children of Abraham" without being circumcised. Mack (:115-117) finds Paul's argument, however, weak and contradictory, and does not think that Paul would have convinced his Galatian opponents:

... subjects, objects, antecedents, and the plain sense of the passages in Genesis were all violated in order to put the construction upon them that Paul did. ... It does not require any training in logic to see how weak this argument is. It does not require any sophistication in linguistics to notice how weird the imagery appears. It is not just that the two applications of the "seed" ... are contradictory, ... or that Paul had to overlook the fact that Abraham was reckoned righteous because he performed the covenant of circumcision ... The main problem was that the thought itself was patently absurd.

What Mack finds particularly troublesome and unacceptable is any vision that extols the own perspective as the only valid one, denigrates that of the other, and implements a missionary program of cultural superiority. He reminds us of Southeast Asia, where missionaries belittled local myths in order to establish their own as the sole truth, or imagines the experience of his own Swedish ancestors when they had to convert to Christianity by force, learning that they were now "children of Abraham" and that their own gods and heroes had to lurk in the shadows (:295). Instead of continuing this mentality, he insists, we will have to propagate an ideal of tolerance between cultures and ethnic groups:

\footnotetext{
Although participation in the markets of a growing global economy appears to be irresistible, the drive to preserve ethnic identities and cultural traditions is resurgent and strong. Recognizing that the world is full of many differing cultures and ways of thinking is the signature of belonging to the postmodern age. ... When one sees that there have been many ways in which people have structured workable societies, developed complex languages, worked out comprehensive symbol systems, ranked ethical and practical values, and
} 
coded behavior appropriate to a sustainable society, the postmodern view of our multicultural world is difficult to reject. It is no longer possible to think that only one worldview must be right $(: 305-306)$.

\section{SOCIAL CLASS}

A second area of criticism concerns Paul's advice on the relationship between the rich and the poor in the Corinthian assemblies. In 1 Corinthians 8 he tells the strong that, if they wish to eat meat sacrificed to Greco-Roman gods, they should consider the weak. Although the strong quite correctly know that there is only one true God and that the gods to whom the city offers their blood sacrifices do not really exist and that eating such meat need therefore not burden one's conscience, Paul points out that the weak do not possess this kind of knowledge and may be confused when they observe the conduct of the strong. Therefore, Paul holds, the strong should refrain from eating such meat in front of the weak in a cultic, official context (in the private context of their homes, away from the eyesight of the poor, it would however probably be in order). It is clear that Paul's ethical stance is determined by his version of the Christ myth, according to which the cross as ultimate model for correct behaviour dictates that the strong should adapt to the needs of the weak.

Gerd Theissen (1982) has argued that "the strong" (oi ioxupórepol) refers to the wealthy minority from the upper classes, while "the weak" (oi a $\sigma \theta \varepsilon v \varepsilon i \varsigma$ ) refers to the majority from the lower classes in the Corinthian house churches, and that Paul's instruction on how the former should behave towards the latter can be termed "love patriarchalism" (Liebespatriarchalismus). This conservative ideology should in his view be rejected as inappropriate for our own times, since it cannot and will not solve any of our own social problems $(: 110,140)$. It in fact "allow[ed] social inequities to continue" (:139).

Seen from our perspective, a better proposal would have been one that did not sustain the subordination of the poor majority to the wealthy minority in the assemblies, but one that instead tried to enlighten the weak to gain the same liberal insight as the strong. Thus, since public sacrifices offered one of the very few opportunities for the poor to get to eat meat, changing their insight to coincide with that of the upper classes 
would have benefited them materially. Theissen speculates that the strong may well have believed "with a very clear conscience" that "they could 'edify' the weak by their example ( 1 Cor 8:10)" and that "the lower classes should not further curtail their already limited possibilities in life" (:140).

\section{GENDER}

A careful reading of 1 Corinthians 7 reveals a Paul fairly conservative with regard to sex and marriage. Although he seemingly insists on equal and mutual sexual responsibilities between male and female, he eventually clearly demands more of women, and thus perpetuates patriarchal interests. What Paul does, according to Antoinette Wire (1990), is to use the "rhetoric of equality" in order to win abstinent women's favour; and then to attempt to persuade them to do the opposite of what they want: they are asked to sacrifice their newly gained freedom, and to offer themselves to men whenever the latter cannot control their lust. Using this rhetoric of equal justice, of course, "requires him to avoid admitting that he is asking more of one sex than the other" (:82), but instead serves to "disguise the gross inequality in his treatment of the woman who has chosen abstinence and the man who lacks "authority over his own desire" (7:37)" (:90). Wire's analysis shows that in the end the unfortunate reality is just this: When speaking about virgins ( $\pi \alpha \rho \theta$ ÉvoI) in the house churches, "Paul leaves.the marriage decision up to the man. ... Paul has replaced the balance of male and female with the balance of two options facing the man (7:36-38). ... The poignant reality is the virgin bound sexually against her decision to the man for his lifetime if he lacks "authority over his own desire" (7:37)" $(: 89)$.

Wire next develops the thesis that the virgins would not have accepted Paul's advice, since they held a theology completely different from Paul's. The content of their God was different from the content of Paul's God. Being free from traditional sexual relations, they saw themselves as consecrated to the service of the Lord, praying in public and experiencing the presence of God's Spirit by prophesying. In Wire's words:

The Corinthian women will not accept the way that Paul sacrifices the authority of God's spirit present in them to the authority of purity standards 
legitimated by God the future judge ... God does not call the women of Corinth to remain as they were when called but transforms their social lives through new sexual choices and responsibilities. Without doubt this is the God of disruption, not [Paul's] God of peace and order. On this basis they reject every attempt to bring forward a God of past structures or future judgment to compromise the living God to whom they are consecrated in body and spirit (:96-97).

\section{HOMOEROTICISM}

Paul's condemnation of same-sex relations constitutes a fourth area of recent criticism. In Romans 1, Paul argues that the gentile nations' worship of their gods has caused God's anger (v 18 ópri่ $\theta \varepsilon o u ̂)$. As punishment for their idolatry God handed them over to their

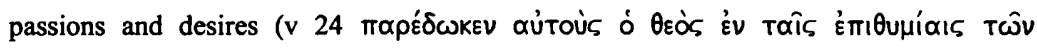

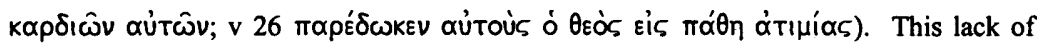
self-control on the part of the gentile nations, says Paul, became evident especially in their perverse sexual behaviour:

Their women exchanged natural intercourse for counter-natural intercourse

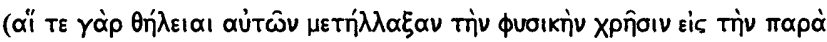
$\phi$ v́oıv), and likewise also the men, abandoning natural intercourse with

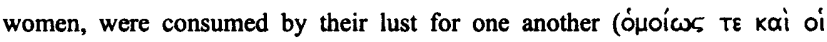

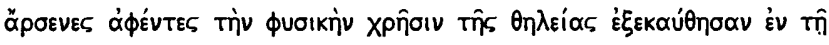

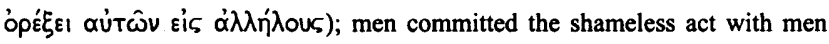

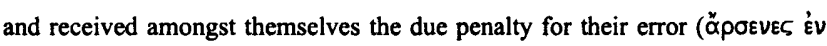

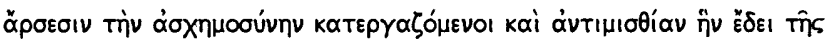

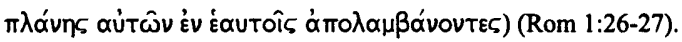

At least in the case of the relationship between two males one should assume that Paul and his audience would have had in mind the Greek convention of pederasty

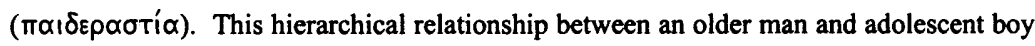
(the former being the active partner who penetrated the latter, passive partner) was idealized and institutionalised in the educational and military system of classical Athens. 
During the Hellenistic period, however, moral philosophers started to criticize the practice. The polemic of Philo, Jewish philosopher of Alexandria and a contemporary of Paul, against pederasty is in agreement with that of his pagan contemporaries. But Philo, of course, explicitly combines this criticism with his exposition of the Jewish law. The passive partner, he holds, should be killed "because he has allowed himself to lose his manliness and to suffer the 'disease of femaleness," while the active partner should be killed "because ... he encourages softness and unmanliness" (Stowers 1994:51).

In a historical study of homoeroticism in the ancient world which is simultaneously concerned about the way in which such a study may contribute to today's debate about homosexuality, the Finnish Old Testament scholar Martti Nissinen (1998) shows that Paul shared "with Josephus, Philo, and others Jewish repugnance toward homoeroticism" (:104). He argues, however, that it is imperative to note that the contemporary question of homosexuality as a relationship between equal partners based on mutual love could not and did not exist in Paul's time. Furthermore, Paul could not and did not conceive of our modern biological, psychological or sociological explanations of sexual orientation. As Nissinen observes: "Paul ... does not know about ... sexual orientation, which is not a voluntary perversion but an aspect of gender identity that manifests itself in different ways, including love. ... Paul ... might have needed sexual therapy as much as any of us" (:124-125).

Nissinen proposes that, in dealing with homosexuals today, the church would do well to take very seriously the ethics of social justice that is so prominent in the prophetic tradition and with the historical Jesus. The real issue should then be formulated as follows: "Homosexuality is part of morality, just as sexuality as a whole is. Homosexuality itself is neither a moral nor an amoral condition, regardless of a theory of its causes. A moral question is how we can and should live as sexual beings in a gendered society and how we treat fellow human beings with different gender identities" (:127).

In line with the condemnation of abuse and exploitation by the prophets and Jesus, the vilification and marginalisation of homosexuals in our societies should likewise be rejected. Although "the boundaries set by society [i.e., the boundaries of conventional gender roles and hierarchical structures] are difficult to cross, even by the power of love" (:134), Nissinen unequivocally holds that "suppression, violence, infidelity, and 
exploitation, on the one hand, and love, responsibility, and empathy, on the other, are the criteria for evaluating any sexual practice" (:127).

\section{A POSITIVE ASSESSMENT}

So far we have surveyed negative assessments of Paul's social experimentation and mythical substantiations. A more positive view is taken by Richard Horsley (1997), who argues that Paul's primary intent was to oppose the ideology and practice of imperial exploitation by creating caring and sharing assemblies throughout the major cities of the eastern part of the Roman empire. If imperial power was exercised by means of patronclient hierarchies and the imperial cult, which proclaimed Caesar as saviour, Paul presented an egalitarian alternative by establishing house churches in the name of Christ as saviour. Two mythologies in conflict. Two dissonant value systems.

Paul, in Horsley's view, for example, refuses financial assistance from the Corinthians "to avoid being pulled into a typical patron-client relationship with one or more of the heads of the households in which the Corinthian assembly members met" $(: 213)$. Or, to cite another example, Paul's collection of money for the poor in Jerusalem "amounted to an international horizontal reciprocal economic relationship, as opposed to the vertical system of tributary relations" (:213). Paul, in other words, resisted "the hierarchical social-economic patronage system by which the whole imperial society became structured and the hierarchical political economy of subject peoples rendering tribute to the empire" (:213).

Although Romans 13 may seem to contradict this reading, Horsley insists that Paul here in no way abolishes his opposition to the imperial ideology, but actually advises Christians, in a particularly volatile situation after the Claudian expulsion of Jews from Rome and at the beginning of Nero's reign, to behave in a judicious way so as not to aggravate their already vulnerable position.

\section{CONCLUSION}

It should be clear by now that, in interpreting texts, we are not merely involved in mental gymnastics. We are, in fact, engaged in politics, which may eventually cause or alleviate the suffering of human beings. Indeed, reading as an ethical act, as a moral responsi- 
bility, cannot and should not be avoided by any humane reader. The authors of The Postmodern Bible summarizes, the whole point well:

Ideological reading ... is a deliberate effort to read against the grain - of texts, of disciplinary norms, of traditions, of cultures. It is a disturbing way to read because ideological criticism demands a high level of self-consciousness and makes an explicit, unabashed appeal to justice. As an ethically grounded act, ideological reading intends to raise critical consciousness about what is just and unjust ..., and to change those power relations for the better. It challenges readers to accept political responsibility for themselves and for the world they live in.

(Aichele et al: 1995:275)

\section{Works consulted}

Aichele, $\mathrm{G}$ et al 1995. The Postmodern Bible: The Bible and Culture Collective. New Haven: Yale University Press.

Boyarin, D 1994. A radical Jew: Paul and the politics of identity. Berkeley: University of California Press.

Crossan, J D 1998. The birth of Christianity: Discovering what happened in the years immediately after the execution of Jesus. New York: Harper San Francisco.

Funk, R W 1996. Honest to Jesus: Jesus for a new millennium. New York: Harper San Francisco.

Horsley, R A (ed) 1997, Paul and Empire: Religion and Power in Roman Imperial Society. Harrisburg: Trinity Press International.

Mack, B L 1995. Who wrote the New Testament?: The making of the Christian myth. New York: Harper San Francisco.

Nissinen, M 1998. Homoeroticism in the Biblical world: A historical perspective. Minneapolis: Fortress Press.

Stowers, S K 1994. A rereading of Romans: Justice, Jews, and Gentiles. New Haven: Yale University Press. 
Theissen, G 1982. Essays on Corinth: The social setting of Pauline Christianity. Edinburgh: Fortress Press.

Wire, A C 1990. The Corinthian women prophets: A reconstruction through Paul's rhetoric. Minneapolis: Fortress Press. 